\title{
Building adaptation to extreme rain effects in San Francisco de Campeche, Mexico
}

\author{
Evelia RIVERA ARRIAGA, Beatriz Edith VEGA SERRATOS*, \\ Gregorio POSADA VANEGAS and Enrique Alejandro MANGAS CHE
}

Instituto de Ecología, Pesquerías y Oceanografía del Golfo de México (EPOMEX), Universidad Autónoma de Campeche, campus VI, Av. Héroe de Nacozari 480, 24070 San Francisco de Campeche, Campeche, México.

*Corresponding author; email: beaevega@uacam.mx

Received: December 2, 2018; accepted: November 21, 2019

\begin{abstract}
RESUMEN
A través de un enfoque integrado de la zona costera, se contribuyó a la adaptación de la ciudad de San Francisco de Campeche, México. Los patrones de lluvia se han comportado de manera diferente de un año a otro y los episodios repentinos y abruptos de lluvia extraordinaria han colapsado e inundado la ciudad en numerosas ocasiones. Se nombró un comité directivo especial para coordinar el plan integrado de manejo costero que operó en los tres niveles de gobierno (federal, estatal y municipal), los cuales unieron esfuerzos para abordar este problema que ha sido una gran amenaza para las personas y la infraestructura en Campeche. Paralelamente, el comité directivo revisó el marco legal para el agua, y la administración municipal proporcionó los planos para el proyecto y diseñó la educación ambiental necesaria para mantener el agua de lluvia más limpia. Se construyó un sistema de drenaje pluvial para separar las aguas residuales de las aguas de lluvia, al tiempo que el sistema de aguas residuales se fortaleció con la mejora de las plantas de tratamiento de agua. Como resultado, la calidad del agua en la zona costera mejoró y la ciudad de San Francisco de Campeche incrementó su resistencia frente a eventos de lluvia extrema que son más frecuentes actualmente debido al cambio climático.
\end{abstract}

\begin{abstract}
An integrated coastal zone management approach was used towards building adaptation strategies for the city of San Francisco de Campeche, Mexico. Large interannual variability in precipitation extremes have led to city-wide flooding in numerous occasions, threatening the population and city infrastructure. A special steering committee was appointed to coordinate an integrated coastal management plan within the three levels of government (federal, state and municipal) and to review the legal framework for water management. The municipal administration designed the blueprint for the project and an associated environmental education campaign. A pluvial drainage system was built to separate pluvial from domestic wastewater. Moreover, the wastewater drainage system was strengthened, and the city water treatment plants improved. As a result, water quality in the coastal zone improved and the city of San Francisco de Campeche was able to build its plan for adaptation to extreme rain events, which are increasingly frequent due to climate change.
\end{abstract}

Key words: Extreme rain events, coastal zone flooding, integrated coastal zone management. 


\section{Introduction}

The Making Cities Resilient (MCR) campaign was launched in 2010 to encourage local government leaders of all countries to adopt disaster risk reduction and build resilience for their cities (UNISDR, 2012). Resilience is defined as the capacity of any entity (an individual, a community or a natural system) to prepare for disruptions, to recover from shocks and stress, and to adapt and grow from disruptive experience (Rodin, 2014). The MCR campaign is supported in the disaster risk reduction (DRR) approach presented in the Hyogo Framework for Action (HFA) 2005-2015 (UNISDR, 2005), which identifies 10 essential tasks that leaders need to address to ensure that hazards risks are reduced and adaptive capacities are built in their cities, namely: (1) organizing and coordinating for resilience, (2) providing a budget and incentives for risk reduction, (3) updating hazard and vulnerability data, (4) investing in risk reduction infrastructure, (5) assessing all schools and health facilities, (6) enforcing risk-compliant building regulations and land use planning, (7) ensuring education programs and training on disaster risk reduction, (8) protecting ecosystems and natural buffers to mitigate hazards and further adaptation to climate change, (9) installing early warning systems and emergency capacities, and (10) ensuring that the needs and participation of the affected population are at the center of reconstruction.

San Francisco de Campeche was founded in October 1540, and up to the middle of the 20th century it lacked pipeline systems to collect domestic wastewater and rainwater. The city was built in a lowland shore with patches of wetlands and to this day, it is surrounded by karst hills with little capacity to drain large volumes of rainwater. Natural channels took care of excess water and directed it to the city, to La Ría (the principal natural drainage channel located in the north part of the city), and to wetland patches that still remain within the city. The oldest part of the city was built considering potential water flow through its streets, especially downtown. But floods during the rainy season were frequent in numerous places within the city.

As the city grew over the following four centuries, wetlands were filled, La Ría was covered, hills were paved, and natural drainage was blocked. Nowadays, extreme rains that occur as the result of climate change, have increased the vulnerability of San Francisco de
Campeche to flooding. Extreme rains leading to risks can be considered as an exogenous phenomenon exacerbated by environmental disorders, which result from poor territorial city planning since the foundation of the city (Elliot et al., 2014). Extreme sea levels and floods are a widespread threat to coastal communities, and extreme rain events are increasing the probability of such events. Coastal flooding may become a significant issue during this century due to sea-level rise, unless there is adaptation (Wadey et al., 2015).

During the past 50 years, the federal, state, and municipal governments partially built a drainage system that collects a percentage of the total volume of domestic wastewater produced in the city, as well as several water treatments plants. However, the combined volume of rainwater and domestic wastewater overburdened water treatment facilities and left the municipal government without capacity to operate the system. Simultaneously, natural channels carried diluted grey water with rainwater, resulting in a "good enough quality", to the seashore with no proper treatment. Coastal water quality studies were carried out between 2007 and 2015, and blueprints were designed to build a new pluvial drainage system, separate from grey discharges. And an integrated coastal zone management plan was designed to address flood issues. This paper documents how San Francisco de Campeche built resilience to extreme events, associated with climate change, through an integrated coastal management approach. The approach included the participation of several sectors, the legal enforcement of the urban development plan, and the coordination of all water-related actors, acknowledging that an integrated approach for the coastal zone was the best way to enhance resilience and build adaptation to climate change.

The purpose of this paper is to describe the conceptual framework and the methodological approach used by the municipal government of Campeche for the implementation of an integrated coastal management plan that led to increased coastal resilience to extreme rain, while improving coastal water quality. This work outlines the activities related to the organization and coordination of resilience, updating hazard and vulnerability data and investing in risk reduction infrastructure (Crichton, 1999). Furthermore, this study provides a set of lessons learned, as well as recommendations for coordinating and implementing 
an integrated complex governance exercise that can be replicated in other coastal regions with similar issues, following the essential tasks proposed by UNISDR (2012).

\section{Materials and methods}

\subsection{Study area}

San Francisco de Campeche is a coastal city with a $\mathrm{A}(\mathrm{w})$ climate and an average temperature of $27.1^{\circ} \mathrm{C}$ that can reach $45^{\circ} \mathrm{C}$. During the rainy season, precipitation may reach $1965.9 \mathrm{~mm}$. The average precipitation used to be about $1043.8 \mathrm{~mm} / \mathrm{yr}$. Population is 233864 with a growth rate of $1.41 \%$ (INEGI, 2010). The high population density, together with lowlands, makes the city prone to climate vulnerability (Dawson et al., 2007). Campeche consumes 3201 of water per person with a potable water demand of $29141 \mathrm{~s}^{-1}$. The 33 water treatment plants operated by the city have a joint treatment capacity of $137.51 \mathrm{~s}^{-1}$; however, the actual volume of domestic wastewater treated is $6.21 \mathrm{~s}^{-1}$, since only $1.8 \%$ of the total homes are connected to the public sewage system, $74.4 \%$ have septic tanks, and there is no information for the remaining 23.8\% (Gobierno de Campeche, 2014).

Drinking water consumed in Campeche comes from the aquifer through the water pipeline system located in the Chiná region, $20 \mathrm{~km}$ away from downtown Campeche. This aquifer is of karstic type; therefore, it percolates a large volume of water, making Campeche dependent on underground water. According to the Comisión Nacional del Agua (National Water Commission) (CONAGUA, 2017), Campeche belongs to the Water Region XII, in the Yucatan Peninsula, and to the RH-31 water sub-region, which covers $25443 \mathrm{~km}^{2}$ and receives $60 \%$ more rain than the national average. Within the $\mathrm{Yu}-$ catan Peninsula, Campeche represents the lowlands, since this region tilts towards the state of Campeche, and water flows from the Peninsula's center towards the coastal zone of Campeche. Rainfall recharges the aquifer, with water flowing through fractures and underground channels underground and in many cases ending up in the sea. It is estimated that the recharge of the aquifer of the Yucatan Peninsula, with an area of approximately $165000 \mathrm{~km}^{2}$, varies between 23 760 and $44800 \mathrm{hm}^{3}$ (Bauer-Gottwein et al., 2011; CONAGUA, 2017).
However, even though fresh water availability is not a problem, water quality is a major issue. High salinity due to the cast and anhydrite dissolution, saline intrusion at the coast, agrochemical runoff, and domestic wastewater discharge, are all sources of water pollution. Moreover, there are no guidelines for building septic tanks in Campeche, where the aquifer is very shallow and there are numerous underground caves carrying fresh water carved in the limestone. This results in coastal water pollution, especially offshore from the old city where many pipelines and septic tanks were built through the years (Rivera et al., 2012).

\subsection{Integrated coastal zone management methodo- $\log y$}

The development of the Integrated Coastal Zone Management (ICZM) for Campeche consisted of three phases: i) hydrological, biological and ecological research and analysis of water and sediment quality, ii) assessment of the institutional capacity to address coastal-marine issues and analysis of the existing legal framework, and iii) evaluation of sectorial involvement and coordination capabilities.

\subsubsection{Hydrological, biological and ecological re- search}

An historical analysis of floods in the city of Campeche was performed, as well as a hydrological analysis focused on the hypothetical increase in number of days with extreme rainfall, and a characterization of the urban basins of the city. The biological studies provided information to generate a comprehensive data base, and allowed the dentification of major issues and conflicts. Moreover, a risk analysis was performed, which led to a proposal of concrete strategies, and recommendations for institutional changes for the preparation and implementation of the ICZM plan.

\subsubsection{Creation of a steering committee for the im- provement of resilience and coastal water quality The Ley de Aguas Nacionales (National Water Act) of Mexico promotes the creation of fresh watershed councils that coordinate the different fresh water stakeholders. These councils are entitled to define the scientific research and management agendas. It is common to create committees within the councils to address particular issues, and in this way the state}


government of Campeche asked the CONAGUA for the creation of this special steering committee that would provide integrated coordination as well as follow-up of the legal, social, economic and political processes required for this task. The steering committee for the improvement of resilience and coastal water quality (STCW) received the IZCM plan prepared by scholars and decided to implement it.

\subsubsection{Definition of issues and tasks}

The STCW invited all sectors from the three levels of government involved in water-resources management to the meetings, as well as members of academic institutions, organized society, and private sector. This expanded committee held monthly meetings over four years (2011-2015) to identify the main issues, to distribute responsibilities, to determine sources of financing for the chosen strategies, and to follow-up the advances in all planned activities according to an established chronogram for each identified issue.

The committee identified major issues for resilience and water quality: $a$ ) point and non-point sources of pollution, $b$ ) urban garbage management, c) capacity of the municipal water-system operator, d) amendments required for the water legal framework, $e$ ) extreme rain events causing floods in extensive sectors of the city, and $f$ ) funding.

\subsubsection{Implementation strategy}

The main water quality project included five lines of action: $a$ ) reinforcing the sanitary pipeline system; $b$ ) building the storm sewage; $c$ ) improving the potable water system; $d$ ) enhancing water treatment plants, and $e$ ) developing an environmental education program. Strategies were proposed for each line of action, including cost/benefit analyses, blueprints were prepared, permits were granted, and the business plans including the three phases were submitted and lobbied to get funding from national and international sources. Political lobbying succeeded, driving presidential attention to the project in order to secure resources for all phases. Phase one was built from 2011 to 2015 . Assessments of the integrated coastal management process were performed for three years, with an evaluation from the federal, state and municipal levels of government at the end of 2015. The state government changed on September 2015 and the new authorities are continuing with the second phase.

\section{Results}

\subsection{Flooding, hydrological and basin analyses}

For a period from 1807 to 2011 (Table I), different parts of the city suffered floods due to upwelling and extreme rains. This table also shows the time-line of engineering structures built since 1950 that have resulted in seashore modification or improvement of the drainage pipeline system.

The climatological station in the city of Campeche, funded by CONAGUA, and operated through the Servicio Meteorológico Nacional (National Meteorological Service), is located at $90.544^{\circ} \mathrm{W}, 19.838^{\circ} \mathrm{N}$, and has 64 years (1952-2015) of accumulated daily rain data. Figure 1 presents the time series of annual precipitation, in which there are missing rain data in 1972 (60 days), in 1973 (32 days), and in 1981 (60 days). The annual average rain is $1043.78 \mathrm{~mm}$, with the highest value $(1965.8 \mathrm{~mm})$ in 1995 associated with hurricanes Opal and Roxanne, which had a dramatic impact in the city of Campeche (Rivera et al., 2003). The lowest values correspond to 1969 , 1982,1983 , and 1997, associated with drought periods for the whole state of Campeche (Cruz, 2017).

Seenath et al. (2015) developed a coastal flood vulnerability assessment to guide coastal management. Palacio et al. (2005) indicate that rainfall accumulations are likely when precipitation rates are higher than $41 \mathrm{~mm} / \mathrm{h}$. Figure $2 \mathrm{a}-\mathrm{c}$ shows the time series of the number of days per five and ten years, that present precipitation larger than 40, 50 and $60 \mathrm{~mm}$.

\subsection{Hydrological basins}

Seven watersheds were identified for the city, based on a digital elevation model (Posada et al., 2013): (1) West, (2) Chapultepec, (3) University, (4) San Román, (5) Central, (6) La Ría and (7) North, which drain independently into the Bay of Campeche (Fig. 3).

The La Ría basin is the largest and has the lowest slope, which causes a slow hydraulic response to rain events. On the other hand, University, Chapultepec and West basins have smaller areas, and their response capacity is fast due to the steepness of the slopes. The physiographic characteristics of all basins are shown in Table II (Mangas, 2018).

The University, San Roman, Central, La Ría and North basins lacked drainage infrastructure, which justified the allocation of funds by the government for the construction of storm drainage in those areas. 
Table I. Historic floods and drainage structures built in San Francisco de Campeche.

\begin{tabular}{|c|c|c|c|}
\hline Date & Cause of floods & Flooded parts of the city & Source \\
\hline $\begin{array}{l}\text { September } \\
1807\end{array}$ & UW & $\begin{array}{l}\text { Floods in different parts of the city up to } 10 \text { th street } \\
\text { downtown }\end{array}$ & Palacio et al. 2005 \\
\hline $\begin{array}{l}\text { October } \\
26,1869\end{array}$ & ER & $\begin{array}{l}\text { Downtown, Santa Ana, La Alameda, Puente de los Perros, } \\
\text { San Román, Santa Lucía, La Ermita, San Francisco and } \\
\text { Guadalupe }\end{array}$ & Palacio et al. 2005 \\
\hline $\begin{array}{l}\text { October } \\
13,1887\end{array}$ & ER & $\begin{array}{l}\text { La Muralla street (today 8th street), Plaza Mayor up to 10th } \\
\text { street, Santa Ana, San Francisco, Guadalupe, San Román }\end{array}$ & Palacio et al. 2005 \\
\hline $\begin{array}{l}\text { September } \\
18,1889 \\
\end{array}$ & ER & Downtown & Palacio et al. 2005 \\
\hline 1911 & ER & $\begin{array}{l}\text { Alameda, 59th street, 14th street, Calle de la Zanja, Puente } \\
\text { de La Viga, Calle del Toro. Floods reported up to } 2 \mathrm{~m}\end{array}$ & Palacio et al. 2005 \\
\hline 1948 & $\mathrm{BRD}$ & $\begin{array}{l}\text { Ría de San Francisco. Building of structures, cleaning and } \\
\text { leveling, } Q_{\mathrm{d}}=2.5 \mathrm{~m}^{3} \mathrm{~s}^{-1} \text {. Until 2014, the Ría collected } \\
\text { sewage waters pouring them directly to the coastal zone }\end{array}$ & Uribe, 1968 \\
\hline$\overline{1948}$ & $\mathrm{BRD}$ & $\begin{array}{l}\text { Building of the rain channel of San Martín }(1260 \mathrm{~m}) \text { for } \\
\text { conveying } 1.44 \mathrm{~m}^{3} \mathrm{~s}^{-1} \text {, located in Santa Ana and the main } \\
\text { market }\end{array}$ & Uribe, 1968 \\
\hline $1962-1967$ & $\mathrm{BRD}$ & Closure of the San Martin channel & Palacio et al., 2005 \\
\hline $\begin{array}{l}\text { September } \\
18,1966 \\
\end{array}$ & $\begin{array}{l}\text { Hurricane } \\
\text { Inés }\end{array}$ & The city was flooded & Pisté, 2012 \\
\hline 1967 & BRD & $\begin{array}{l}\text { Building of Central Avenue's rain channel to mitigate floods } \\
\text { in Fracciorama and Central Avenue. However, it could not } \\
\text { be connected to the San Martín channel }\end{array}$ & Uribe, 1968 \\
\hline $\begin{array}{l}\text { September } \\
12,1969\end{array}$ & $\mathrm{BR}, \mathrm{UW}$ & $\begin{array}{l}\text { Flooding of 14th street, old electric plant, Puente de los } \\
\text { Perros, La Alameda, Tamarindo Bus Station, San Martín } \\
\text { channel, low areas of Santa Lucía, La Ría, Reparto de } \\
\text { Kalá valley and surroundings, as well as both sides of the } \\
\text { Campeche-Mérida highway }\end{array}$ & Palacio et al., 2005 \\
\hline 1980 & $\mathrm{BRD}$ & Beginning of the Fracciorama-San Martín channel & Palacio et al., 2005 \\
\hline $\begin{array}{l}\text { August 21, } \\
1981\end{array}$ & Cold front & Flood of Gobernadores Avenue $\left(97.3 \mathrm{~mm} \mathrm{day}^{-1}\right)$ & Palacio et al., 2005 \\
\hline $\begin{array}{l}\text { September } \\
14,1988\end{array}$ & $\begin{array}{l}\text { Hurricane } \\
\text { Gilbert }\end{array}$ & $\begin{array}{l}\text { Floods of downtown, south of the city and all over the city. } \\
\text { Three meters high waves and upwelling up to } 450 \mathrm{~m} \text { inland. } \\
\text { Col. Solidaridad Nacional }(1.50 \mathrm{~m} \text { flood })\end{array}$ & Palacio et al., 2005 \\
\hline $\begin{array}{l}\text { June 16, } \\
1994\end{array}$ & $\mathrm{BRD}$ & $\begin{array}{l}\text { Beginning of the Plan Chac channel: Jaina Avenue, Ruiz } \\
\text { Cortines Avenue, Casa de Justicia, López Mateos, Ah Kim } \\
\text { Pech neighborhood, Plan Chac, Presidentes de México, } \\
\text { Colonia México, Fidel Velásquez, Pablo García, Dzarbay }\end{array}$ & Palacio et al., 2005 \\
\hline $\begin{array}{l}\text { September } \\
30,1995 \\
\end{array}$ & $\begin{array}{l}\text { Tropical } \\
\text { depression }\end{array}$ & $\begin{array}{l}\text { Floods of Álvaro Obregon Avenue, Gobernadores Avenue } \\
\text { and the Social Security Hospital (IMSS) }\end{array}$ & Palacio et al., 2005 \\
\hline June 23, 1995 & ER & $\begin{array}{l}\text { Flooding of Ciudad Concordia, San Martín, La Ría de San } \\
\text { Francisco, Pedro Sainz de Baranda market, La Alameda, } \\
\text { Circuito Baluartes, IMSS, Central Bus Station, López } \\
\text { Mateos Avenue and Gobernadores Avenue }\end{array}$ & Palacio et al., 2005 \\
\hline
\end{tabular}

UW: upwelling; ER: extreme rain; BRD: building of rainwater drainage 
Table I. Historic floods and drainage structures built in San Francisco de Campeche.

\begin{tabular}{|c|c|c|c|}
\hline Date & Cause of floods & Flooded parts of the city & Source \\
\hline $\begin{array}{l}\text { September } \\
30,1995 \\
\end{array}$ & $\begin{array}{l}\text { Hurricane } \\
\text { Opal }\end{array}$ & $\begin{array}{l}\text { Generalized floods in the city with } 15 \text { thousand people } \\
\text { affected and } 10 \text { casualties }\end{array}$ & Palacio et al., 2005 \\
\hline $\begin{array}{l}\text { October 3, } \\
1995\end{array}$ & $\begin{array}{l}\text { Hurricane } \\
\text { Roxanne }\end{array}$ & Generalized floods within the city (154 $\mathrm{mm} \mathrm{day}^{-1}$ of rain) & Palacio et al., 2005 \\
\hline $\begin{array}{l}\text { June 15, } \\
1999\end{array}$ & ER & $\begin{array}{l}\text { Floods in 45th street at the Barrio de Guadalupe, Privada } \\
\text { del Sol, Solidaridad Urbana, Fidel Velásquez, López Mateos } \\
\text { Avenue, around Pedro Sainz de Baranda market, Plan Chac, } \\
\text { Cumbres }\end{array}$ & Palacio et al., 2005 \\
\hline $\begin{array}{l}\text { September } \\
24,2002\end{array}$ & $\begin{array}{l}\text { Hurricane } \\
\text { Isidore }\end{array}$ & $\begin{array}{l}\text { Floods of La Ría, Planc Chac, Presidentes, Fracciorama } \\
2000 \text {, Héroe de Nacozari, IMSS park, El Carmelo, } \\
\text { FOVISSSTE Belén, Moch Cohuó park, Legislative House, } \\
\text { Minas, San Martín park, Santa Lucía and La Esperanza }\end{array}$ & Palacio et al., 2005 \\
\hline $\begin{array}{l}\text { June 15, } \\
2004\end{array}$ & ER & $\begin{array}{l}\text { Floods in Jaina Avenue, Ruiz Cortines, Casa de Justicia, } \\
\text { López Mateos Avenue, Ah Kim Pech commercial zone, } \\
\text { Plan Chac, Presidentes de México, Fidel Velásquez, Pablo } \\
\text { García and Dzarabay ( } 50 \mathrm{~mm} \text { day }^{-1} \text { of rain) }\end{array}$ & Palacio et al., 2005 \\
\hline 2005 & $\begin{array}{l}\text { Hurricane } \\
\text { Emily, ER }\end{array}$ & Minor damage in San Francisco de Campeche & Pisté, 2012 \\
\hline 2005 & $\begin{array}{l}\text { Hurricane } \\
\text { Stan }\end{array}$ & $\begin{array}{l}\text { Floods in Gobernadores Avenue, Central Avenue, and López } \\
\text { Mateos Avenue }\end{array}$ & Pisté, 2012 \\
\hline $\begin{array}{l}\text { June 29, } \\
2010\end{array}$ & $\begin{array}{l}\text { Hurricane } \\
\text { Alex }\end{array}$ & $\begin{array}{l}\text { Floods in Presidentes de México, Colosio Avenue, Fidel } \\
\text { Velásquez, Paraguay and Querétaro streets, Gobernadores } \\
\text { Avenue, Patricio Trueba Avenue, López Mateos Avenue, } \\
\text { Ruiz Cortines Avenue, Querétaro street }\end{array}$ & Pisté, 2012 \\
\hline 2011 & $\begin{array}{l}\text { Tropical storm } \\
\text { Arlene }\end{array}$ & $\begin{array}{l}\text { Largest floods were located in Patricio Trueba Avenue, Fidel } \\
\text { Velázquez, Presidentes de México at Juan Magan, Ah Kim } \\
\text { Pech commercial zone, Miguel Alemán Avenuw, La Ría, } \\
\text { Agustín Melgar Avenue, Adolfo Ruiz Cortinez Avenue, Gas } \\
\text { station Pedro Sainz at the coastal zone }\end{array}$ & Pisté, 2012 \\
\hline
\end{tabular}

UW: upwelling; ER: extreme rain; BRD: building of rainwater drainage

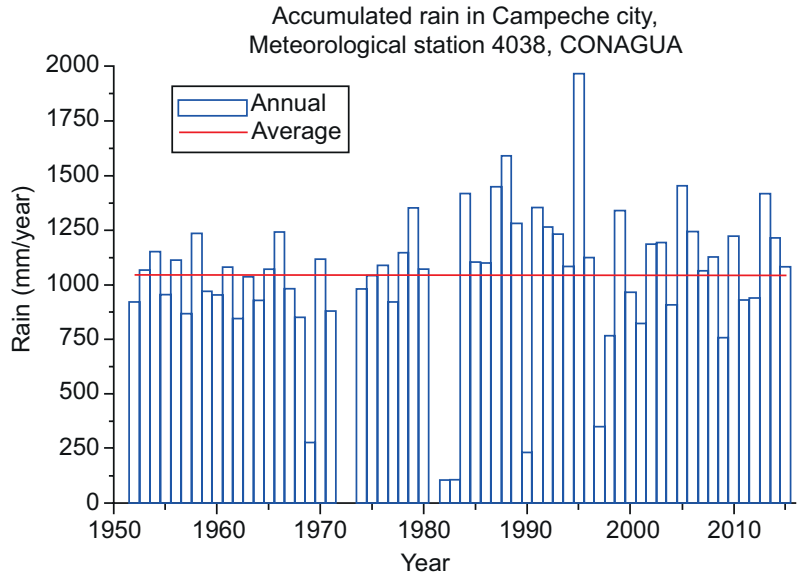

Fig. 1. Annual rain for the city of Campeche (source: CONAGUA, 2018).
The integral network of pluvial drainage consists of $20 \mathrm{~km}$ in length, with rectangular sections from 4 to $12 \mathrm{~m}^{2}$. The final configuration, concluded in the year 2015, is shown in Figure 4 (Mangas, 2018).

\subsection{Building adaptation}

The ICZM Plan for San Francisco de Campeche was prepared by consensus by all stakeholders of the three levels of government, and also the private sector, academics and representatives of the organized society (Torresan et al., 2016). This ICZM process could be used for improving the negotiation and coordination of the three levels of government, as well as all related-sectors, the affected community, societal needs and the necessary scientific knowledge 
(a)

Days with accumulated rainfall greater than $40 \mathrm{~mm}$,

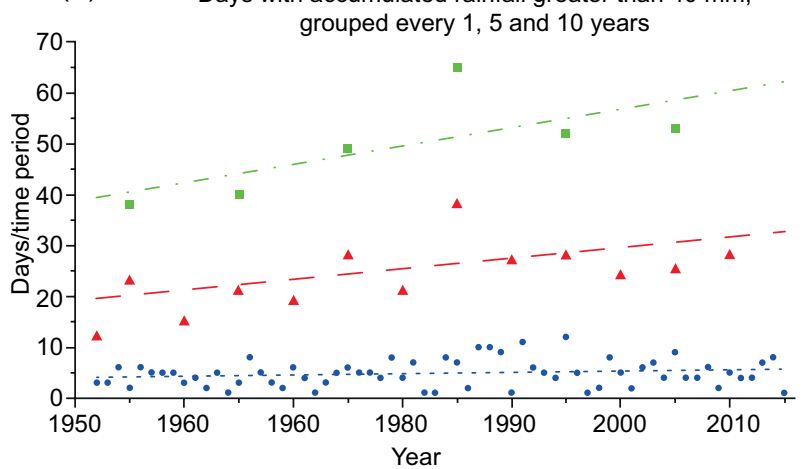

(c)

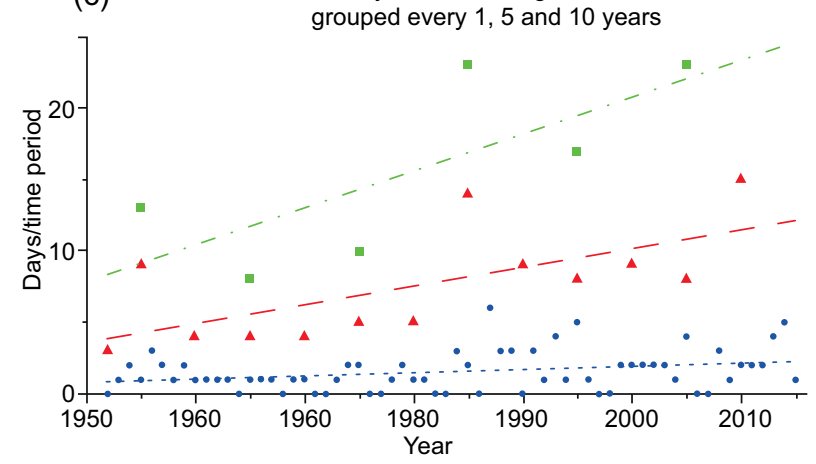

(b)

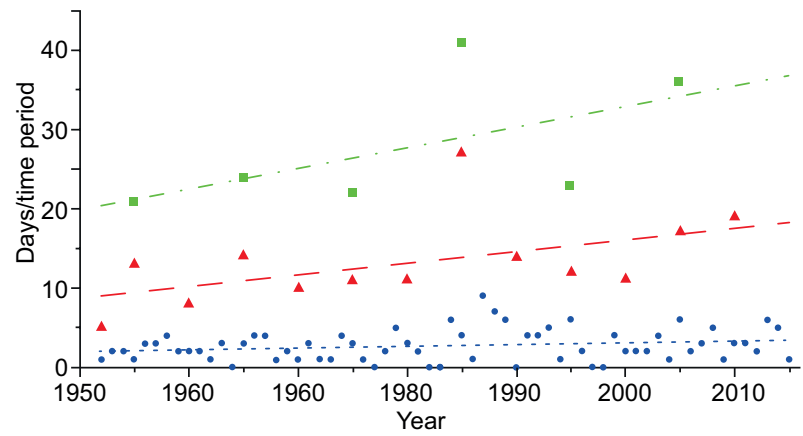

Fig. 2. Number of days with precipitation larger than (a) $40 \mathrm{~mm}$, (b) $50 \mathrm{~mm}$, and (c) $60 \mathrm{~mm}$, every 1, 5 and 10 years.

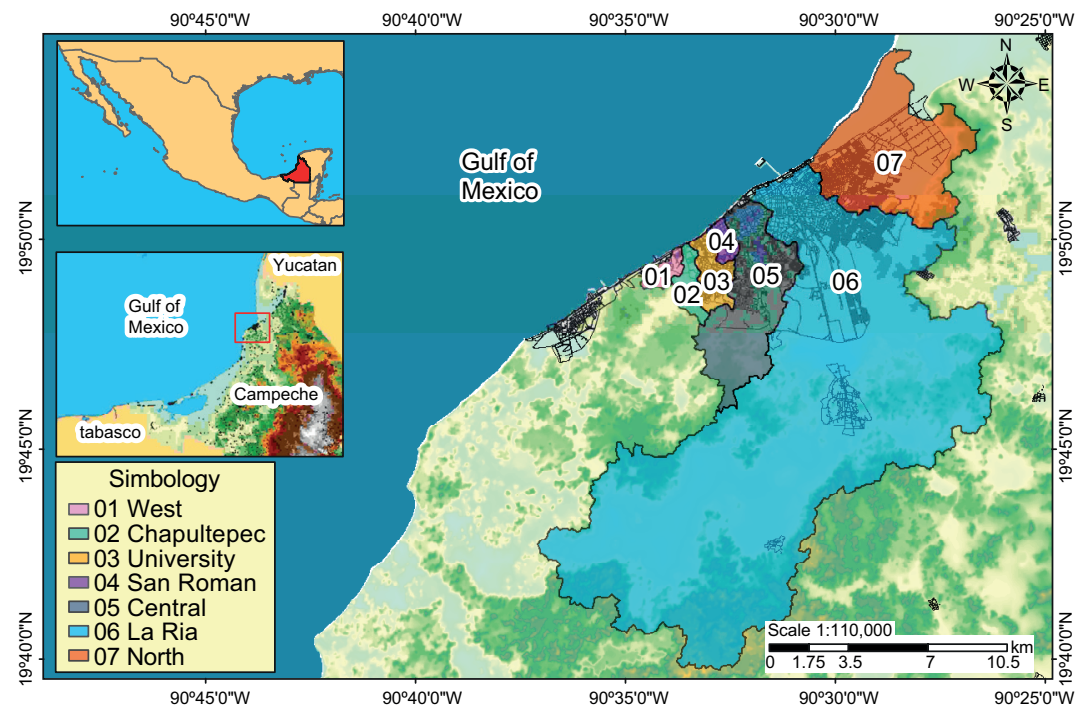

Fig. 3. Watersheds for the city of San Francisco de Campeche.

to support decision making based on consensus and science (Portman et al., 2015). Building adaptation through the implementation of the ICZM considered the points detailed in the following subsections.

\subsubsection{Members of the ICZM coordination group} This group was led and coordinated by the state government, with the Governor as its head, CONAGUA as the acting sectorial part, and the state minister of 
Table II. Physiographic characteristics of the watersheds of San Francisco de Campeche.

\begin{tabular}{lrrcl}
\hline Watershed & $\begin{array}{c}\text { Surface } \\
\left(\mathrm{km}^{2}\right)\end{array}$ & $\begin{array}{c}\text { Perimeter } \\
(\mathrm{km})\end{array}$ & $\begin{array}{c}\text { Main stream } \\
\text { length }(\mathrm{km})\end{array}$ & Slope \\
\hline West & 1.73 & 7.04 & 2.07 & 0.025 \\
Chapultepec & 2.53 & 9.84 & 3.22 & 0.01588 \\
University & 3.77 & 11.68 & 3.44 & 0.01381 \\
San Roman & 1.66 & 5.78 & 1.95 & 0.009 \\
Central & 19.77 & 29.98 & 10.45 & 0.006 \\
La Ría & 174.19 & 102.46 & 15.6 & 0.00403 \\
North & 28.92 & 31.02 & 8.53 & 0.00658 \\
\hline
\end{tabular}

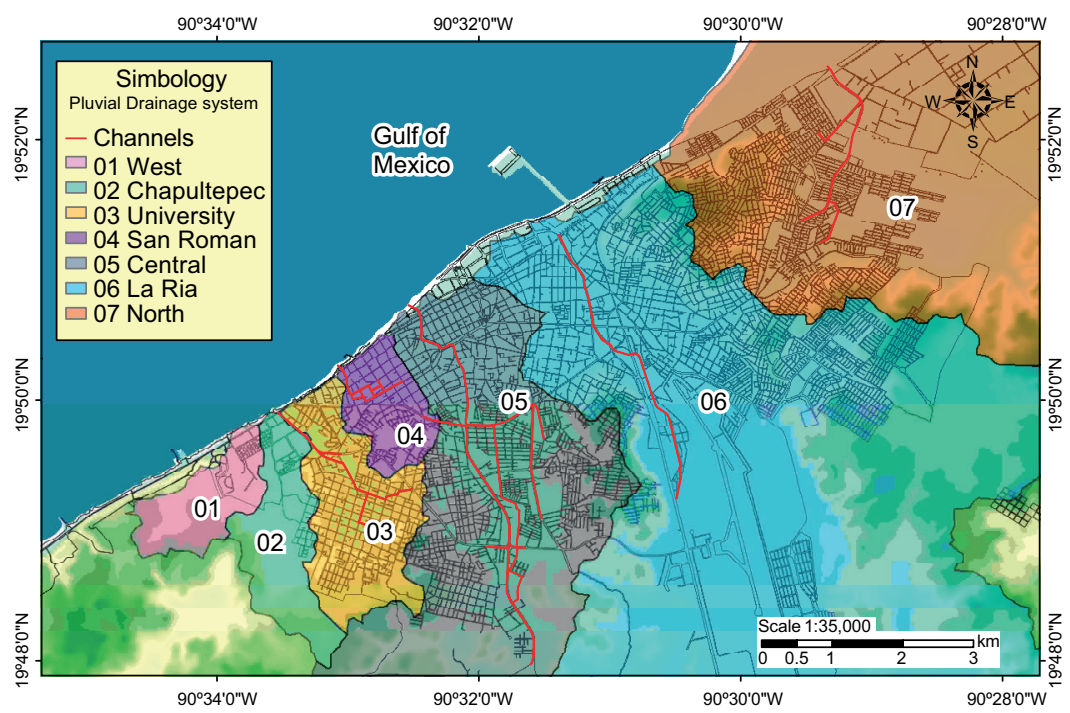

Fig. 4. Hydraulic infrastructure built during the period 2010-2015.

the Environment as the main coordinator. The tasks of this group were: (1) to identify all the necessary actions and products to be addressed for both flood risk and coastal water quality improvement; (2) to organize the agenda and work meetings; (3) to fulfill the objectives according to the given time-schedules; (4) to obtain the governmental permits and making the required studies; (5) to follow-up advances per working group; (6) to maintain data bases and files; (7) to identify critical issues and solving problems; (8) to settle disputes by negotiating, through all the steps and with all parties; and 9) to seek and get the required funding for operation.

\subsubsection{Main issues identified}

- Risk and vulnerability to floods: Risk zones prone to floods within San Francisco de Campeche were identified and population risks assessed (Guevara et al., 2006; Posada et al., 2015). The assessment included information on socioeconomic subsystems (such as demographic, economic, and landuse developments), and on climate change, (such as potential sea level rise, subsidence, hydrology and accumulated water), and considered different economic scenarios.

- Coastal water quality: Land sources of pollution were identified, and the environmental quality of marine water and ecosystems was evaluated. The Mexican regulatory framework for marine water quality is given by the Official Mexican Standard NOM-001-ECOL-1996 (SEMARNAT, 1997), which specifies the maximum pollutant levels allowed for different uses, including nature and recreation purposes, and NOM-022-SEMARNAT-2003 
(SEMARNAT, 2003), which seeks the protection of mangroves and coastal wetlands through the quality of their hydrology, among other elements.

- Municipal sanitary pipeline system: The institutional capacity of the system was assessed regarding its legal framework, administrative processes, operative capacity, leak and water fees studies, and the status of water treatment plant considering technology transfer.

- Garbage municipal system: It involved the assessment of the institutional capacity for collecting and final disposal of garbage, composition and leaks, as well as soil infiltration of lixiviates that pollute underground water.

- Land holding scheme: Properties and their statu quo considering their purchase or expropriation for the construction of pluvial drainage.

- Pluvial drainage design and blueprints: A suitable rain drainage project was designed taking into consideration: (a) flood risk and vulnerability information, (b) topography of the city, (c) watersheds, $(d)$ coastal water quality, and $(e)$ tides.

- Social and economic impacts: Disruptions (e.g. streets obstruction, noise and dust emissions) resulting from construction activities were evaluated, as well as economic losses due to blocking avenues and access over construction time (12 months).

- Sensitization and environmental education program: For both purposes, the fact that disruptions derived from the construction phase would prevent future floods was acknowledged, and the fact that coastal water quality would be improved through public participation and better garbage disposal was recognized.

- Studies and governmental permits: Environmental impact assessment permits, legal quotas for the construction materials, and cost/benefit studies were obtained for the public building project.

- Search for funding: A pre-feasibility economic study was developed considering all the above, as well as the executive project for defining the financial requirements $(i)$ to prepare the project file, (ii) to seek funding, (iii) to construct every single phase and (iv) to operate the system.

- Follow-up by the organized civil society: Considering both environmental and civil protection issues involved in this project, the organized society was incorporated from the beginning so that it could constantly monitor and verify that everything was done according to the legal framework and the agreements made with affected population and businesses.

\subsubsection{Creation of working groups}

In order to tackle each one of the identified main issues, 10 working groups within the STCW were formed, and responsibilities were assigned to each one of the participants:

- Risk and vulnerability to floods: Civil Protection Agency, State Ministry of Government, municipal director of Public Works.

- Coastal water quality: State Ministry of the Environment, State Ministry of Health, University of Campeche.

- Municipal sanitary pipeline system: municipal director of Water, municipal and state directors of Public Works.

- Garbage municipal system: State Ministry of the Environment, municipal director of Public Works.

- Land holding scheme: State Ministry of Government, State Cadaster Institute.

- Pluvial drainage design and blueprints: CONAGUA, State Ministry of Public Works.

- Social and economic impacts: State Ministry of Commerce and Industry, State Ministry of Finance.

- Sensitization and environmental education program: State Ministry of Environment, municipal director of Environment.

- Studies and permits: State Ministry of Environment, State Ministry of Public Works.

- Funding searching: State Ministry of Finance, State Ministry of Administration, State Ministry of Auditing, CONAGUA

- Organized civil society: State Minister of Government, State Minister of the Environment

\section{4 Assessment on the advances of each issue}

The STCW worked for three years worked in all the above steps to prepare the ICZM plan. Every two weeks the STCW summoned each working group to report progress achieved, issues encountered, and needs discussed, as well as the best way to tackle them. A very important coordination task was the 
scheduling of all activities, studies, permits and works in an orchestrated fashion to facilitate administrative, legal and economic requirements. Another equally important chore was to coordinate public works from the three levels of government to make sure that once construction started in an avenue or street, all cables, pipelines, etc., were in place to avoid social and economic costs. The STCW also dealt with media and non-governmental organizations by providing one single channel for communicating the official version to the public, which diminished speculation and confusion.

\subsection{Decision-making process and implementation}

Transparency and accountability were mandatory throughout the ICZM process. The STCW was in charge of the project, and presented the ICZM plan to different sectors, the three levels of government and academics, for review. A number of comments and recommendations were given to the STCW, which were included and taken into consideration for the different steps of the project. During the operation process, decision-making was consensual in every single STCW meeting with the representatives of all the parties. The decision-making process was documented through proceedings that were signed by every party at the end of each meeting. Reports were written and sent to the heads of each sector, the governor and the civil society.

Problems arose during the implementation phase and the STCW had to made decisions to solve them in the best possible way. All issue-groups had appointed a contact person that communicated directly their requirements issues and needs to the STCW. This procedure avoided delays, major issues, and cascade problems. An important asset of the STCW coordination was the avoidance of duplication efforts, as well as the optimization of a cost-efficient use of funding and materials. Moreover, the implementation had to fulfill civil defense requirements as well as the coastal water quality improvement that the public was expecting.

\section{Discussion}

As mentioned above, the ICZM is the appropriate approach for addressing complex and dynamic processes such as those occurring in coastal zones.
Tailoring adaptation policies to address floods requires a comprehensive, holistic and integrated process to assess the type and scope of future problems and to find opportunities to reduce risks (Klijn et al., 2012). The ICZM methodology was adapted to the local context, climate change effects, regional culture, social structure, economy, policy, coastal-marine environment, technology availability, scientific stock and knowledge, human behavior, scale and administrative periods, and institutional capacity, among other elements. Through the ICZM process in Campeche, it was possible to understand the natural risks, to strengthen governance through adaptation, and to improve preparedness for future hydrometeorological phenomena. Moreover, the IZCM process helped to identify leaderships in the task of decreasing the risk of flooding and it contributed to building resilience (Khunwishit et al., 2018). Designing and implementing an ICZM governance for the city of San Francisco de Campeche was a major task and required political endorsement at the highest level, sectorial commitment, and a shared vision that translated into common objectives and achievable goals. The decision-making process of the ICZM plan was built following the approach described by several authors (Thia-Eng, 1993; Fabbri, 1998; Cicin-Sain and Knecht, 1998; Westmacott, 2001; Lau, 2005; Sardá et al., 2005; McFadden, 2007; McKenna et al., 2008; Groot et al., 2010; Ramesh, 2011; Khunwishit et al., 2018).

\subsection{Addressing coastal vulnerability}

The vulnerability of Campeche's coastal zone to hazards, such as extreme rain events, is increasing due to poor land planning, population growth and insufficient hydraulic infrastructure. The pressures of development and climate change set the pace in this accelerating process (Karrasch et al., 2014). For effective coastal governance, it is imperative to address the vulnerability of coastal settlements to climate-related hazards (Flannery et al., 2015). This is particularly the case of the city of San Francisco de Campeche, where development planning and control have a direct impact on vulnerability.

Reducing the vulnerability of coastal populations, risk mitigation and adaptation strategies need to be built into local spatial planning processes such as the integrated coastal zone management for Campeche 
city. The local, state and federal governments operate within a complex hierarchal framework which may promote or limit any particular actions regarding hydrological processes and flooding. It is important, therefore, to understand how local coastal planning practices are shaped by national and supranational entities in order to design a coordinated intervention to address any issue (Flannery et al., 2015).

The municipal and state governments of Campeche had to respond to the demands of local population regarding floods, and ICZM evolved into the governance framework to enhance the policy cycle for decision-making (Ehler, 2003). The ICZM process in Campeche allowed to address and overcome all the barriers confronting participatory governance. The successful actions and lessons learned were continuously applied, resulting in recommendations for moving forward (Kearney et al., 2007). In compliance with article 115 of the Mexican constitution, the government shifted many coastal management responsibilities to local governments and fostered local participation in the management of coastal resources. In the delivery of ICZM as a basic service, Campeche achieved increasing public awareness of the management of coastal resources issues.

The environmental assessment of coastal waters enhanced science-policy integration and was useful to disseminate knowledge across sectors. During the numerous STCW meetings, planning hierarchy and regulatory commissions were effective mechanisms to integrate policies across government levels, with the latter also promoting public-government integration. Several economic instruments -such as the urban development plan, the environmental territorial plan and the Los Petenes Natural Protected Area management plan- had to be jointly analyzed and, in some cases, limited.

Results of this study also contribute to evidence-based coastal management by identifying the obstacles related to the mechanisms of integration in the case of addressing extreme events. While planning coastal risk management strategies, coastal managers need to assess risks across a range of spatial and temporal scales. For coastal extreme events, the ICZM considers flood hazards and its related damages; therefore, the building of resilience encompasses more governance complexity than traditional vulnerability or hazard approaches (IPCC, 2012).

\subsubsection{Urban growth and coastal water quality}

The expanded urban settlements in Campeche face increased risks in the light of climate change. Urban population has increased and is forced to cope with flooding and coastal water pollution. Old coastal cities, such as San Francisco de Campeche, have major coastal water quality problems. Over the past 50 years, the city footprint has experienced growth along the coast through land-filling, in an attempt to provide public services as well as more land for commerce and tourism investors. The process involved cutting down mangroves, the loss of a small sand beach, and changes to the coastal marine zone and its associated changes to benthic fauna and flora. Constant changes in the coastal profile, altered oceanographic processes, and land availability resulted in hotels building and the expansion of commerce and tourism-related services. Additionally, poor institutional capacity and low investment in public services are a recipe for disaster.

The water quality issue was addressed by the STCW, which received the support of academics who had performed several environmental, social and institutional studies in constructing a baseline that allowed to coordinate actions and made collective decisions through the ICZM program. In Mexico, coastal and marine zones are under the jurisdiction of the federal government; therefore, states and municipal governments may be able to suggest and recommend actions in those areas but are legally unable to perform any activity nor take any decision without the approval of the federal government.

The governance challenge is to manage climate-related impacts in an urban context by promoting planned and autonomous adaptation in order to improve resilience for extreme rain events in changing climate (Tanner et al., 2009). The ICMZ plan identified the impacts, accounting for societal needs and ecosystem services in the coastal zone.

The municipal government is responsible for building and operating the freshwater pipeline system, the distribution of fresh water, and the collection, cleaning and discharge of domestic wastewater. However, this is a weak level of government with poor capacity and scarce funding to perform any action during its three-year period of governance. On the other hand, the state government does not have any jurisdiction over municipal decisions but is entitled to 
provide aid whenever is needed. Moreover, the state may be able to collaborate and even seek funding for municipal actions on behalf of the wellness of the public. Furthermore, these two levels of government must act in accordance with the National Development Plan, federal actions are defined by generalized national policies that seek the improvement of coastal water quality and building resilience in coastal zones facing climate change events (Climate Change Act).

\subsection{Flood risk}

Klijn et al. (2015) indicate that it is important to plan adaptive flood risk management based on a policy analysis that provides a future perspective for a required policy transition, an evaluation of possible flood risk management strategies, and early planning to avoid doing too little too late or too much too early. Building adaptation through the ICZM plan called for innovative approaches, accounting for uncertainties in long-term future urban developments. These authors postulate that flood risk management should consider basic principles, tailoring and implementing portfolios of technical measures, jointly with an urban development plan together with other policy instruments.

Disaster risks arise when physical hazards interact with social, economic and environmental vulnerabilities. Hydrometeorological events are often associated with the majority of disasters. Despite the growing understanding and acceptance of the importance of disaster risk reduction and increased disaster response capacities, disasters, and in particular the management and reduction of risks, continue to represent a challenge for Campeche.

There is now international acknowledgement that efforts to reduce disaster risks must be systematically integrated into policies, plans and programs for sustainable development and poverty reduction, and should be supported through bilateral, regional and international cooperation, including partnerships. The following are some of the previous international efforts to reduce disaster risks:

- The Yokohama Strategy for a Safer World: provides guidelines for natural disaster prevention, preparedness and mitigation. Its Plan of Action, adopted in 1994, provides landmark guidance to reduce disaster risks and the impacts of disasters.
- The World Conference on Disaster Reduction adopted the Framework for Action 2005-2015 "Building the resilience of nations and communities to disasters".

- The Sendai Framework for Disaster Risk Reduction 2015-2030, which is the first major agreement of the post-2015 development agenda, with seven targets and four priorities for action.

This study demonstrates the importance of the ICZM plan, not only because it is coherent with the Sendai Framework, but also for understanding and systematizing the factors that lead to risks, as well as leading and supporting the successful implementation of disaster risk reduction and adaptation. Moreover, Khunwishit et al. (2018) examined the effects of leadership on the disaster resilience of a city and the positive effect of flood resilience building on a city's progress.

Since municipal governments in the state of Campeche last only three years, the state governments (which lasts six years) have more experience and possibilities to deal with risk management. Having chosen the ICZM as a methodology to deal with risks, the state government had the ability to influence, communicate, and enlist sectorial heads, as well as city residents, to agree on and support the disaster risk reduction strategy and adaptation building of the city.

The STCW needed to negotiate adaptation building with federal authorities, since adaptation encompasses more complexities than a traditional vulnerability or hazards approach (Flood and Schechtman, 2014). After all, floods due to extreme rain events often lead to city collapse, and ICZM may address both goals through the same strategy. As this work highlights, the importance of policy, legal frameworks, environmental education, cost/ benefit analysis, and hydrology and geography studies for the coastal management area became evident during the governmental intervention. The fostering of the ICZM governance framework, as well as a clear linkage between climate adaptation and the management of the coastal zone of Campeche, underlines the effective coordination and communication among actors and users. The ICZM exercise may help to examine whether this concept represented a paradigm shift or it maintains the dominant sectorial 
perspective of earlier hazard mitigation approaches under a new guise.

The Campeche project faced continuing challenges (especially financial sustainability), inadequate capacities, weak law enforcement, and lack of integrated and collaborative efforts. To address these challenges, the emerging governance system improved strategies and promoted incentives for the local government to support ICZM. This system is being applied by an increasing number of local governments for guiding the development and implementation of ICZM in their jurisdictions (White et al., 2007).

\section{Conclusions}

The design and implementation of an Integrated Coastal Zone Management plan for the city of San Francisco de Campeche was an important mechanism to address coastal water quality as well as floods. As mentioned, the ICMZ plan cover many sections from scientific research all the way to policies and recommendations for effective implementation. We summarize here a few of the main conclusions.

On the climatological context: Hydrological analysis of rainfall data in San Francisco de Campeche allowed the identification of a continuous growth in the number of days per year with rain over the 40, 50 and $60 \mathrm{~mm}$ thresholds. From de period 1952-2015, the number of days per year over the $40 \mathrm{~mm}$ threshold went from 4 to 6 for the period, each five years from 20 to 32 days, and from 39 to 61 days each 10 years. The 50 and 60 thresholds present a similar behavior, the number of days each 10 years went from nine in the period 1951-1960 to 22 in the 2001-2010 decade. While the annual precipitation does not change over the period considered, there is an increase in the number of days with extreme rainfall. These results justify the investment to build a pluvial drainage and to lower the risk of floods, building resilience and adaptation to climate change.

On coastal water quality: As part of the ICZM plan, the municipal government strengthened the potable water delivery system and separate pluvial and wastewater discharge system, as well as building a sanitary filling and increasing garbage colleting capability, all of which led to improved coastal water quality. Moreover, the mangrove forests, that are part of the city of San Francisco de Campeche, were cleaned, preventing garbage from filling their channels and obstructing the hydrological system.

On flood risk management: Flood risk to decision-makers means not only estimating probability of flooding but also considering consequences of flooding, particularly given the pre-existing large vulnerability. The adopted ICZM plan provides a multiple-tiered approach to flood risk management. The flood risk adaptation path followed by the government of San Francisco de Campeche, involved assessing all the policy options to evaluate the degree of change provided, allowing built-in flexibility and adaptation to the process.

On policy and governance: While conventional adaptation management may rely on trial-and-error and sound monitoring of developments, the adaptive strategy implemented in San Francisco de Campeche recognizes the need for action even in the face of information uncertainties in climate change signal (Diermanse et al., 2010). This case pointed out the physical threshold levels which required a policy transition. Substantial work was done to improve water governance capacity, public awareness, environmental quality improvement and flooding control, which resulted in a more resilient coastal zone. A state water act proposal was developed as a contribution to the integrated coastal zone management.

The first phase of the ICZM plan was concluded in 3 years through several integrated management actions that were developed in a parallel about crosscutting issues such as health, tourism, economic development of the waterfront, etc. (Nagy et al., 2018). A major achievement was the continuity of the IZCM plan for the following government administration, which will conclude the second phase. The third phase will take another 6 years, with the objective of achieving zero pollution from coastal water discharges and a fully resilient coastal zone. In summary, the coastal city of San Francisco de Campeche is now more resilient to extreme rain events due to the ICZM approach for tackling two major issues that were connected and solved through an integrated approach.

\section{Acknowledgments}

The authors want to thanks all reviewers that helped to improve the quality of this work, which is part 
of the project Evaluation and Characterization of Hydrology and Hydraulics of San Francisco de Campeche city.

\section{References}

Bauer-Gottwein P, Marín LE, Rebolledo-Vieyra M, Merediz-Alonso G. 2011. Review: The Yucatán Peninsula karst aquifer, Mexico. Hydrogeology Journal 19:507-524.

DOI 10.1007/s10040-010-0699-5

Cicin-Sain B, Knecht R. 1998. Integrated coastal and ocean management. Island Press, $543 \mathrm{pp}$.

CONAGUA. 2017. Estadísticas del Agua en México. Comisión Nacional de Agua, Mexico. Available at: www.gob.mx/conagua (accessed December 4, 2018).

CONAGUA 2018. Mexican daily climatological information. Comisión Nacional de Agua, Mexico. http:// smn.cna.gob.mx/es/component/content/article?id=42 (accessed December 4, 2018).

Crichton D. 1999. The risk triangle. In: Natural disaster management (Ingleton J, Ed.). Tudor Rose, London, $320 \mathrm{pp}$.

Cruz KC. 2017. Analysis of droughts in the state of Campeche. M.Sc. thesis. Campeche Autonomous University, Campeche, Mexico.

Dawson R, Hall J, Barr S, Batty M, Bristow A, Carney S, Evans S, Ford A, Köhler J, Tight M, Walsh C. 2007. A blueprint for the integrated assessment of climate change in cities (draft, v. 1.2). Working paper 104. Tyndall Centre for Climate Change Research. Available at: http://citeseerx.ist.psu.edu/viewdoc/download?doi $=10.1 \cdot 1.128 .21 \& \mathrm{rep}=$ rep $1 \&$ type $=$ pdf

Diermanse FLM, Kwadijk JCJ, Beckers JVL, Crebas JI. 2010. Statistical trend analysis of annual maximum discharges of the Rhine and Meuse rivers. British Hydrological Society Third International Symposium, Newcastle.

Ehler CN. 2003. Indicators to measure governance performance in integrated coastal management. Ocean and Coastal Management 46:335-345.

DOI: 10.1016/S0964-5691(03)00020-6

Elliot M, Cutts ND, Tromo A. 2014. A typology of marine and estuarine hazards and risks as vectors of change: A review for vulnerable coasts and their management. Ocean and Coastal Management 93:88-99.

DOI: 10.1016/j.ocecoaman.2014.03.014
Fabbri KP. 1998. A methodology for supporting decision making in integrated coastal zone management. Ocean and Coastal Management 39:51-62.

DOI: 10.1016/S0964-5691(98)00013-1

Flannery W, Lynch K, Cinnéide MO. 2015. Consideration of coastal risk in the Irish spatial planning process. Land Use Policy 43:161-169.

DOI: 10.1016/j.landusepol.2014.11.001

Flood S, Schechtman J. 2014. The rise of resilience: Evolution of a new concept in coastal planning in Ireland and the US. Ocean and Coastal Management 102, part A:19-31.

DOI: 10.1016/j.ocecoaman.2014.08.015

Gobierno de Campeche. 2014. Quinto Informe de Gobierno. Anexo estadístico. Gobierno del Estado de Campeche, Mexico, 582 pp.

Groot RS, Alkemade R, Braat L, Hein L, Willemen L. 2010. Challenges in integrating the concept of ecosystem services and values in landscape planning, management and decision making. Ecological Complexity 7:260-272.

DOI: 10.1016/j.ecocom.2009.10.006

Guevara O, Quaas W, Fernández V. 2006. Lineamientos generales para la elaboración de atlas de riesgos. In: Conceptos básicos sobre peligros, riesgos y representación geográfica. Serie: Atlas Nacional de Riesgos. Centro Nacional de Prevención de Desastres, Mexico.

INEGI, 2010. Instituto Nacional de Estadística y Geografía, Mexico. Available at: http://www.beta.inegi.org.mx/ app/tabulados/pxweb/inicio.html?rxid=d518b312-a3 2e-4d23-a8dd-08a64c187a6c\&db=Poblacion\&px=poblacion_03 (accessed December 04, 2018).

IPCC. 2012. Managing the risks of extreme events and disasters to advance climate change adaptation. A special report of working groups I and II of the Intergovernmental Panel on Climate Change (Field CB, Barros V, Stocker TF, Qin D, Dokken DJ, Ebi KL, Mastrandrea MD, Mach KJ, Plattner GK, Allen SK, Tignor M, Midgley PM, Eds.). Cambridge University Press, Cambridge and New York, 582 pp.

Karrasch L, Klenke T, Woltjer J. 2014. Linking the ecosystem services approach to social preferences and needs in integrated coastal land use management - a planning approach. Land Use Policy 38:522-532.

DOI: $10.1016 /$ j.landusepol.2013.12.010

Kearney J, Berkes F, Charles A, Pinkerton E, Wiber M. 2007. The role of participatory governance and community-based management in integrated coastal and 
ocean management in Canada. Coastal Management 35:79-104.

DOI: $10.1080 / 10.1080 / 08920750600970511$

Klijn F, Knoop J, Ligtvoet W, Mens MJP. 2012. In search of robust flood risk management alternatives for the Netherlands. Natural Hazards and Earth System Sciences 12:1469-1479. DOI: 10.5194/nhess-12-1469-2012

Klijn F, Kreibich H, De Moel H, Penning-Rowsell E. 2015. Adaptive flood risk management planning based on a comprehensive flood risk conceptualization. Mitigation and Adaptation Strategies for Global Change 20:845864. DOI: $10.1007 / \mathrm{s} 11027-015-9638-\mathrm{z}$

Khunwishit S, Choosuk C, Webb G. 2018. Flood resilience building in Thailand: Assessing progress and the effect of leadership. International Journal of Disaster Risk Science 9:44-54. DOI: 10.1007/s13753-018-0162-0

Lau M. 2005. Integrated coastal zone management in the People's Republic of China-An assessment of structural impacts on decision-making processes. Ocean and Coastal Management 48:115-159.

DOI: 10.1016/j.ocecoaman.2005.03.002

Mangas EA. 2018. Evaluation of drainage system of the city of San Francisco de Campeche. M.Sc. thesis, Campeche Autonomous University, Campeche, Mexico.

McFadden L. 2007. Governing coastal spaces: The case of disappearing science in integrated coastal zone management. Coastal Management 35: 429-443.

DOI: $10.1080 / 08920750701525768$

McKenna J, Cooper A, O’Hagan AM. 2008. Managing by principle: A critical analysis of the European principles of integrated coastal zone management (IZCM). Marine Policy 32:941-955.

DOI: 10.1016/j.marpol.2008.02.005

Nagy GJ, Leal Filho W, Azeiteiro UM, Heimfarth J, Verocal JE, Li C. 2018. An assessment of the relationships between extreme weather events, vulnerability, and the impacts on human wellbeing in Latin America. International Journal of Environmental Research and Public Health 15, 1802. DOI: 10.3390/ijerph15091802

Palacio G, Salles P, Silva Casarín, R., Bautista EG, Posada G, Val R. 2005. Diagnóstico por inundación para la ciudad de Campeche. Universidad Autónoma de Campeche/H. Ayuntamiento del Municipio de Campeche, Mexico, 109 pp.

Pisté C. 2012. Evaluation of flooding hazard in the city of San Francisco de Campeche before the occurrence of extreme hidrometeorological phenomena (hurricanes),
B,SC, thesis in Biology. Universidad Autónoma de Campeche, Mexico.

Portman M, Dalton TM, Wiggin J. 2015. Revisiting integrated coastal zone management: Is it past its prime? Environment: Science and Policy for Sustainable Development 57: 28-37.

DOI: $10.1080 / 00139157.2015 .1001693$

Posada Vanegas G, Vega Serratos BE, Silva Casarín R, eds. 2013. Peligros naturales en el estado de Campeche. Cuantificación y protección civil. Universidad Autónoma de Campeche/CENECAM/Gobierno del Estado de Campeche/CENAPRED, Mexico, 202 pp.

Posada Vanegas G, Vega Serratos BE, Domínguez Mora R, Silva Casarín R. 2015. Riesgos naturales en el estado de Campeche. Universidad Autónoma de Campeche/ CENECAM/Gobierno del Estado de Campeche/CENAPRED, Mexico, $264 \mathrm{pp}$.

Ramesh DA. 2011. Methodology of integrated coastal zone management plan preparation - Case study of Andaman Islands, India. https://www.researchgate. net/publication/267968931_Methodology_of_Integrated_Coastal_Zone_Management_Plan_Preparation-Case_Study_of_Andaman_Islands_India (accessed November 23, 2017).

Rivera Arriaga E, Lara Domínguez AL, Villalobos Zapata G, Yáñez-Arancibia A. 2003. Trophodynamic ecology of two critical habitats (seagrasses and mangroves) in Términos Lagoon, southern Gulf of Mexico. In: From Mexico to Brazil: Central Atlantic fisheries catch trends and ecosystem models (Zeller D, Booth S, Mohammed E, Pauly D. Eds.). The Fisheries Centre Research Report, vol. 11, No. 6. University of British Columbia, 245-254.

Rivera Arriaga E, Alpuche Gual L, Negrete Cardoso M, Nava Fuentes JC, Lemus PE, Arriaga Zepeda C. 2012. Programa de manejo integrado para el saneamiento de la bahía de San Francisco de Campeche. Universidad Autónoma de Campeche, Mexico, 68 pp.

Rodin J. 2014. The resilience dividend: Being strong in a world where things go wrong. Public Affairs, New York, $374 \mathrm{pp}$.

Sardá R, Avila C, Mora J. 2005. A methodological approach to be used in integrated coastal zone management processes: the case of the Catalan Coast (Catalonia, Spain). Estuarine, Coastal and Shelf Science 62:427-439. DOI: 10.1016/j.ecss.2004.09.028

Seenath A, Wilson M, Miller K. 2015. Hydrodynamic versus GIS modelling for coastal flood vulnerability 
assessment: Which is better for guiding coastal management? Ocean \& Coastal Management 120:99-109. DOI: 10.1016/j.ocecoaman.2015.11.019

SEMARNAT. 1997. Norma Oficial Mexicana NOM001-ECOL-1996. Que establece los límites máximos permisibles de contaminantes en las descargas de aguas residuales en aguas y bienes nacionales. Diario Oficial de la Federación, January 6. Available at: http:// dof.gob.mx/nota_detalle.php?codigo $=4863829 \&$ fecha $=06 / 01 / 1997$

SEMARNAT. 2003. Norma Oficial Mexicana NOM-022SEMARNAT-2003. Que establece las especificaciones para la conservación, aprovechamiento sustentable y restauración de los humedales costeros en zonas de manglar. Diario Oficial de la Federación, April 10. Available at: http://www.profepa.gob.mx/innovaportal/ file/3281/1/nom-022-semarnat-2003.pdf

Tanner T, Mitchell T, Polack E, Guenther B. 2009. Urban governance for adaptation: Assessing climate change resilience in ten Asian cities. IDS Working Paper 315:1-47. DOI: 10.1111/j.2040-0209.2009.00315_2.x

Thia-Eng C. 1993. Essential elements of integrated coastal zone management. Ocean and Coastal Management 21:81-108. DOI: 10.1016/0964-5691(93)90021-P

Torresan S, Critto A, Rizzi J, Zabeo A, Furlan E, Marcomini A. 2016. DESYCO: A decision support system for the regional risk assessment of climate change impacts in coastal zones. Ocean \& Coastal Management 120:49-63. DOI: 10.1016/j.ocecoaman.2015.11.003
UNISDR. 2005. Hyogo framework for action 2005-2015: Building the resilience of nations and communities to disaster. United Nations International Strategy for Disaster Reduction, Geneva. Available at: https://www. unisdr.org/we/inform/publications/1037 (accessed October 14, 2019).

UNISDR. 2012. How to make cities more resilient: A handbook for local government leaders. United Nations International Strategy for Disaster Reduction, Geneva. Available at: https://www.unisdr.org/we/inform/publications/26462 (accessed October 14, 2019).

Uribe A. 1968. Historia de inundaciones, paludismo, petróleo en Ciudad del Carmen y Campeche. Campeche, México, 576 pp.

Wadey MP, Cope SN, Nicholls RJ, McHugh K, Grewcock G, Mason T. 2015. Ocean \& Coastal Management 116:237-247. DOI: 10.1016/j.ocecoaman.2015.07.028

Westmacott S. 2001. Developing decision support systems for integrated coastal management in the tropics: Is the ICM decision-making environment too complex for the development of a useable and useful DSS? Journal of Environmental Management 62:55-74.

DOI: $10.1006 /$ jema.2001.0420

White A, Deguit E, Jatulan W, Eisma-Osorio L. 2007. Integrated coastal management in Philippine local governance: Evolution and benefits. Ocean \& Coastal Management 34:287-302. DOI: $10.1080 / 08920750600686687$ 